\title{
Tripartite periodization of the Antarctic Treaty system from a systemic perspec- tive $^{1}$
}

\author{
Periodización tripartita del Sistema del Tratado An- \\ tártico desde una perspectiva sistémica
}

Mônica Heinzelmann Portella de Aguiar²

Resumen: En 1959, doce países con alto grado de interés en la Antártida firmaron un Tratado para permitir el libre acceso a la investigación científica pacífica. El Tratado Antártico estableció la ciencia y la cooperación internacional como su base, pero generó controversias al aceptar reclamos de soberanía sobre el territorio antártico. Esta investigación tiene como objetivo llenar un vacío bibliográfico al proponer una estricta periodización del Sistema del Tratado Antártico desde una perspectiva sistémica. El artículo también examina la adhesión de Brasil al Tratado. Utilizando como indicadores de legitimidad el aumento en la membresía y la transparencia de los procesos de toma de decisiones, el autor sostiene que el Sistema del Tratado Antártico pasó a ser reconocido como un régimen internacional legítimo.

Palabras clave: Sistema del Tratado Antártico; Relaciones Internacionales; regímenes internacionales; perspectiva sistémica; cooperación internacional.

Abstract: In 1959, twelve countries with a strong record of interest in Antarctica signed a Treaty allowing accessibility to all signatories wishing to conduct peaceful scientific research. The Antarctic Treaty established science and international cooperation as its cornerstones but raised controversies because of its hosting of sovereignty claims over Antarctic territory. This research aims to fill a gap in literature proposing a strict periodization of the Antarctic Treaty System under a systemic perspective. The paper also examines Brazil's accession to the Treaty. Using as indicators of legitimacy the increase in membership and the transparency of decision-making processes, the author argues that the Antarctic Treaty System has come to be recognized as a legitimate international regime.

\footnotetext{
DOI: https://doi.org/10.24215/23142766e054

${ }^{1}$ Recibido: 23/03/2019. Aceptado: 30/04/2019.

${ }^{2}$ Associate Professor at UCAM. PhD in Political Sciences/International Relations by IUPERJ/UCAM (2016). Researcher at Nucleo de Estudos Avançados (NEA) of Instituto de Estudos Estratégicos (INEST/ Universidade Federal Fluminense). Master in Sociology and Politics PUC/RJ. Email: monicahpaguiar@gmail.com
} 
Keywords: Antarctic Treaty System; International Relations; international regimes; systemic perspective; international cooperation.

This paper's first objective is to investigate the transformation of the regime established by the Antarctic Treaty System (ATS) from a systemic perspective, by explaining its changes based on the attributes of the international environment and the internal contradictions of the regime, and disregarding the states as variables (Keohane, 1983). Whilst not aspiring to provide an exhaustive account, we propose to examine the ATS diachronic trajectory and separate it in three blocks of time in order to identify which political, economic and environmental drivers helped shape each one of them. Historical categorization observes restricted and debatable criteria that are convenient to the scholar but may unintentionally deplete the phenomenon of its complexity. Such a framework, however, if based on solid historical foundations, can be useful for a comprehensive assessment of the shifting pattern of the ATS. The second goal is to verify Brazil's accession to the ATS, emphasizing how it was the first country to withdraw from the bipolar logic that distinguished the prior affiliation to the Treaty and how this enabled other global southern states to sign up as well.

The temporal periodization demarks each phase, proposing years and concrete episodes to correlate the international context with the ATS milestones. Though the analysis of circumstances around the signature and ATS evolution are recurrent in academic work discussing the Antarctic, such literature usually approaches the ATS phases with broad boundaries, focusing more on the regime's internal dynamics than on the external drivers responsible for its changes. Experts like Hemmings (2009; 2011; 2012; 2013; 2017) and Chatuverdi (1986; 2011; 2013; 2015) refer to the regime history as a background to debate present issues related to it or to analyze the Australian and Indian positions in the ATS.

The three phases of the ATS display different characteristics. The first one proceeds under the logic of the Cold War and bipolar dynamics, and portrays a still incipient regime with few partners (1961-78). The second phase stands out through the massive admission of new state actors and an increase in the transparency of their relationships (1979-91). The last phase strengthens the previous changes (1992- to date).

According to Young (2011), the effectiveness of an international regime stems from its degree of legitimacy and fairness. Based on this understanding, the second objective of this paper is to measure the advance of ATS legitimacy, using the increase in membership and the access to decision-making processes as indicators. The concept of regime used in this paper observes the definition provided by Krasner (1983), as the set of principles, norms, rules and procedures around which the players of international relations converge. Krasner distinguishes between change within the regime and change of regime. The first case is more commonplace and entails a simple correction of rules and procedures, whereas the change of regime presupposes a qualitative transformation, when there is an alteration of the principles and norms that define its nature.

The twelve original signatories to the ATS negotiated an agreement that ensured their own powerful interests whilst excluding the rest of the world from it. In due time, the regime evolved as a result of a new balance of power and of its own dynamic nature. The consultative members, along the way, adapted the ATS rules and decision-making procedures so as to make them more transparent and inclusive. By examining the ATS trajectory, it will be possible to assess how, despite the corrections in its procedures and rules, its principles and norms remained the same, characterizing a change within the regime, but not of regime. 
These changes allowed the ATS to overcome controversy and achieve the representativeness and legitimacy that led to its permanence.

\section{Before the Treaty}

Until 1959, and due to its geographic characteristics, Antarctica lacked legal status. Discovered in 1822, it only began to attract interest in the Twentieth Century, when the first claims to sovereignty occurred. Seven countries, arguing discovery or contiguity, announced their claims over the Terra Nullius: United Kingdom (1908), New Zealand (1923), France (1924), Australia (1933), Norway (1939), Chile (1940) and Argentina (1942).

The Antarctic Treaty (1959) was an attempt to give international status to the continent and, at the same time, not to contradict the claims of sovereignty. The solution was to postpone the claims indefinitely, without putting an end to them. In Washington, twelve countries accommodated the recognition and moratorium of territorial aspirations with the project of preserving the continent for scientific research. These countries were summoned to the conference because, the year before, during the International Geophysical Year (IGY), they had established scientific research bases in the Antarctic continent. The seven claimant countries agreed to defer their claims without renouncing them (Article IV), and the continent became accessible to the Treaty signatories committed to peaceful research. The regime intended to safeguard the region from the political/military/environmental standpoint, and to promote "international co-operation in scientific investigation in Antarctica" (Article III).

Furthermore, the Treaty overcame the scenario of bipolar dissent and guaranteed cooperation among the signatories: United States, Union of Soviet Socialist Republics, Argentina, Australia, Belgium, Chile, France, Japan, Norway, New Zealand, United Kingdom and Union of South Africa. Although legal, the exclusion of a significant part of the world community in the management of a vital continent for the planet's sustainability jeopardized the international legitimacy of the regime. To survive, the agreement would need to become more inclusive and transparent. This indeed happened and today the ATS has 53 signatories.

\section{For consultative members only: the reserved first phase (1961- 1978)}

The first phase starts with the Antarctic Treaty coming into force on 23 June 1961 and ends seventeen years later, when the inclusion of a further agreement, the Convention for the Conservation of Antarctic Seals (1978), transformed the Treaty into a system ${ }^{3}$. All other additional conventions and protocols were signed in the next phase.

\footnotetext{
${ }^{3}$ The Antarctic Treaty System consists of the original Treaty, to which the following were added: the Convention for the Conservation of Antarctic Seals (1972), the Convention on the Conservation of Antarctic Marine Living Resources (1980) and the Madrid Protocol (for environmental protection - 1991). In 1969, the Vienna Convention on the Law of Treaties provided a legal framework for all international agreements signed between sovereign states. The ATS has also an association called Scientific Committee on Antarctic Research (SCAR), which is responsible for coordinating scientific activity and advising the ATS on everything
} 
In the early 1960s, a sequence of incidents increased the friction between the United States and the Soviet Union. The Bay of Pigs invasion (April 1961), the construction of the Berlin Wall (August 1961) and the Missile Crisis (October 1962) happened in sync with an unprecedented development of military technology. Despite the sense of impending conflict, both Washington and Moscow avoided open confrontation and agreed to implement external policies of dissuasion and peaceful coexistence. The dissuasion concept was to persuade the adversary of the damaging power of mutual retaliation. Peaceful coexistence, even without embracing peace, acknowledged the existence of the other superpower and admitted the principles of sovereignty, respect for territorial integrity, non-aggression and non-interference in domestic affairs.

According to this paper's first objective, it is possible to assert the role of the global structure of power on the composition of the ATS. The bipolar nature of international relations dominated the process of joining the regime. Initially, only the Warsaw Pact member countries, Poland (1961), Czechoslovakia (1962), Romania (1971), East Germany (1974), Bulgaria (1978) and the NATO countries, Denmark (1965) and the Netherlands (1967), signed the agreement.

The Soviet Union sought to offset the geopolitical imbalance of a Treaty with a majority of pro-Western States, calling on their satellites to join the regime. Moreover, Brazil's accession to the ATS in 1975 was a turning point in this binary scenario. The avant-gardism of the Brazilian case is interesting. With the exception of the original members (Argentina and Chile), Brazil was the first non-European country, uncommitted to the two main military alliances of the world, to sign the Antarctic Treaty.

In the constellation of Soviet satellites joining the ATS, special attention should be given to the absence of the People's Republic of China, the most populous communist country in the world and with the potential of playing a decisive role in the balance of the regime. The USA, allied with Nationalist China (Formosa), prevented the inclusion of "Red China" in major international projects and organizations. During the preliminary meetings of the Treaty in Washington, the admission system to the ATS was the subject of much controversy. The Soviet Union advocated admitting into the Treaty all States with which the original members maintained diplomatic relations, an initiative that would allow access to China. The United Kingdom, however, supported restricted membership: only the Member-States of the United Nations Organization (UN), of which the PRC had been excluded since 1949, could be admitted. The negotiated solution was to approve access to the UN MemberStates, but allowing others to be suggested, as long as the original and active members agreed ${ }^{4}$. This provision enabled the consultative parties to exercise a veto power and compromised the balance of power sought by the USSR (Costa, 1961).

concerning this topic. Together, the ATS and SCAR encompass both the diplomatic and scientific management of the continent. With regard to the frequency of meetings since 1994, ATS consultative members have met annually instead of every two years. With the entry into force of the Madrid Protocol (1998), the committee for the protection of the environment also meets annually. Special conferences - which serve to address specific issues - continue to be convened on a random basis. Expert organisations such as the International Association of Antarctica Tour Operators (IAATO), the Council of Managers of National Antarctic Programs (COMNAP), Antarctic and Southern Ocean Coalition (ASOC) and others, act as observers during ATS meetings.

${ }^{4}$ All consultative members which acquired this status after the original twelve are considered active members. Article XIII of the Treaty details the conditions for accession. 
In this initial phase, the Sino-Soviet alliance already showed the first signs of the fissure that would lead to a diplomatic rupture in 1964 . The divergences between both countries were geopolitical and ideological. The Chinese revolution had initially been hailed by Moscow as a victory of international communism, but it soon became clear that the neighboring country would not align with or submit to the Soviet order. From the 1970 s and in a motion of Realpolitik, China sought a strategic rapprochement with the United States that eventually led to its admission to the UN and its access to the ATS during the second phase.

When the ATS came into force, four countries in the world possessed nuclear technology. The USA was the precursor with the USSR following closely. The United Kingdom and France also developed their nuclear programs and helped foster the continued arms race between the two hegemons.

Although the destructive potential of nuclear weapons was wellknown, the isolation and emptiness of Antarctica encouraged the Americans to defend the site as an international deposit of radioactive waste and location to perform tests. Argentina, backed by the countries of the southern hemisphere and the Soviet Union, called for a ban on any procedure of military nature, nuclear explosions and the disposal of radioactive materials. The signing of the Treaty on the non-proliferation of Nuclear Weapons (1968) sustained this trend, restricting this technology to the permanent members of the UN Security Council.

In 1961, environmental issues had not yet been introduced into the international political agenda. The release of books such as "Silent Spring" (Carson,1962) and "Avant que Nature meure" (Dorst,1965) aroused public opinion on the harmful effects of industrial progress. As the civil society in developed economies became aware of the risks of human activity on the planet, the debate acquired a more political bias, whose outcomes were the conference of the Biosphere (Paris 1968) and the United Nations Conference on the Human Environment (Stockholm 1972). Their goal was to avoid the advance of the environmental degradation of our habitat. With regard to Antarctica, the environmental discussion remained at the conservationist level and prioritized the fauna, leading up to the Convention for the Conservation of Antarctic Seals.

In 1973, the rise in the price of oil finally buried the three decades of continuous growth that had characterized the post-war economic recovery. Some structural evidences foreboded the crisis: developed economies lived the challenge of financing an advanced model of social welfare in the midst of declining industrial productivity. Though moderate, unemployment and inflationary trends persisted. The collapse of the Bretton Woods order and changes in the international financial system due to the end of the dollar-gold parity worsened the situation and resulted in the oil crisis.

Faced with the devaluation of the dollar and an insufficient readjustment index to recover the loss of purchasing power in gold per barrel, the OPEC countries decided to negotiate a price increase with the oil companies. In October 1973, the Yom Kippur war cut short the talks and broke off the deal. The rise in the price of oil sank the world into an unprecedented energy and economic crisis, hindering the productive activity that depended on fossil energy source.

The international crisis had a direct impact on the meetings' content of the ATS consultative members. Antarctic mineral exploration, formerly discarded, was once again included in the discussion agenda. From 1974 on, it became a regular subject in all sessions, whether they were expert meetings or informal working groups (Qasim and Rajan, 1985). At the consultative meeting in London (1977), it was recommended that the parties agree 
on a regulatory regime prior to undertaking mineral exploration activity. One of the factors that motivated the great demand for the regime in the next phase was the expectation of an ATS revision.

\section{Brazil's accession to the ATS}

Brazil, unlike Argentina and Chile, who promptly roused to the importance of Antarctica, ignored the very presence of the continent until the eve of the IGY $Y^{5}$ This position was representative of the priority given by Brazilian geopoliticians to ensure the occupation of the inner regions of a country the size of a continent. The first Brazilian considerations on Antarctica were set forth by geopoliticians Therezinha de Castro and Delgado de Carvalho who, in 1956, submitted a Frontage theory inspired by Pascal Poirier's Sector theory for the splitting of the Arctic.

According to them, Antarctica should be divided among all the South American coastal countries that faced the white continent: Argentina, Brazil, Chile, Ecuador, Peru and Uruguay. In this regard, Brazil would be entitled to a section claimed by both the United Kingdom and Argentina (Ferreira, 2009). The Frontage theory had a strategic-military focus and expressed the military concern for national security. The authors even recommended the installation of air control bases in Antarctica. For a better understanding of this proposal, we have to remember that the Inter-American Treaty of Reciprocal Assistance (Rio Treaty 1947) planned for the union and defense of the American continent, included in its strategic area, a fraction of Antarctica claimed by Argentina, Chile and United Kingdom as well as a fraction that could be claimed by the United States ${ }^{6}$.

The IGY, held between 1957 and 1958, coincided with the Presidency of Juscelino Kubistchek, the onset of his Goals Program and the construction of the new capital. Brazil cooperated in the IGY, but was oblivious to the importance of a more active participation in its scientific project. It installed data processing bases only in the national territory and did not send an expedition and/or settled a base in the Antarctic continent. It was not known, then, that this would be the convening criterion for participation in the Washington conference.

When Brazil discovered it had been excluded from the conference, it reacted through diplomatic channels and sent a formal note of protest to the US Embassy (07/30/1958). It complained that all the American countries with political, economic or strategic interests in Antarctica should have been invited to participate. Brazil needed to protect its extensive and exposed coastline and national safety was reason enough to justify its interest in Antarctica. There was a fear that the Cold War could reach southern regions, especially due to the Soviet Union presence in the area and recent warning of unidentified submarines in South American territorial waters. Thus, the Brazilian government reserved its right to free access of Antarctica and to claim what it deemed necessary and felt free from complying with any deliberation that failed to satisfy it (Bath, 2000).

\footnotetext{
${ }^{5}$ Argentina and Chile were the last countries to formalize their territorial claims. This delay is due to not having considered, until then, the need to justify their sovereignty before the world, for since their independence from Spain they had considered their territories as extending up to the South Pole.

${ }^{6}$ It was Argentinian pressure that expanded the safety zone covered by the Rio Treaty to include the South Pole sector, also claimed by the United Kingdom.
} 
Brazil's protest caused little repercussion in domestic and foreign policy. Internally, Brazil pursued industrial economic development, while internationally it sought to strengthen relations with other South American countries. Kubistchek launched the PanAmerican Operation, aiming to fight economic underdevelopment (and the risk of communism) through a joint multilateral policy with the rest of Latin America. Brazil's aspiration was to exercise more influence over the region and it deliberately chose not to antagonize the concrete interests of Argentina and Chile in the Antarctic continent. In the international system, regardless of being the largest country in Latin America and the fifth in the world, Brazil remained a peripheral player who hardly affected the whole. Lacking a clear position on the Antarctic matter, Brazil decided to go along with the international alternative.

Throughout the 1960s, under the Jânio Quadros / João Goulart's administrations or under the military dictatorship, little progress was made on the subject. Before the coup, the Independent Foreign Policy sought a higher international insertion for Brazil through dialogue and partnerships with countries that could respond to national needs, even if not aligned with American interests (Viana, 2009). During the first military mandates, due to ideological affinities related to anti-communist discourse, there was a deeper alignment with the United States, favoring the east-west antagonism in detriment of the north-south one (Cervo and Bueno, 2012).

In the 1970s, many circumstances helped change Brazil's perception of Antarctica. If, at the beginning of the decade, Brazil boasted high growth rates due to the "economic miracle", in the following years the oil crisis, the collapse of Bretton Woods and the decrease in the pace of economic growth caused a transformation of both the national context and of Brazilian foreign policy. Under Ernesto Geisel's administration, responsible pragmatism developed a model of foreign relations based less on ideological matters and more on Brazil's taking part in other political and economic co-operations. South-south relations and relations with the African and Asian continents were consolidated (Cervo and Bueno, 2012). This new policy allowed Brazil to play a more assertive role concerning Global South settings and introduced a novel approach towards Antarctica.

Somewhat paradoxically, the early 1970 s coincided with new support arrangements given to the Frontage theory by Federal Deputy Eurípides Cardozo de Menezes, Therezinha de Castro's friend. The deputy, who had attended the Escola Superior de Guerra (Brazilian War College) and defended a paper entitled "Antarctica, international interests", called for Brazilian presence in the continent (Mattos, 2015). His mobilization led to the creation, in September 1972, of the Brazilian Institute for Antarctic Research, a private entity related to the Engineering Club, which tried to organize a scientific expedition to the continent. The initiative was not met by the government's approval since it could regionally be interpreted as a provocation to Argentina and would reverse the order of events internationally, promoting the mission prior to accession of the Treaty.

Under Geisel's administration, Brazil finally determined its position on the matter of Antarctica. Brazil gave up the Frontage theory, supported by the militaries, and accepted Itamaraty's thesis, devised by diplomat João Frank da Costa. Recognizing the Treaty as the only valid instrument for the governance of the region, the expert had recommended joining the ATS and gaining consultative status. In spite of the existing divergences between Brazil and Argentina, the affiliation to the ATS was considered timely as it had the merit of eluding the political conflict between the two countries over the construction of the Itaipu hydroelectric plant. By giving up the principle of territoriality of the Frontage Theory, Brazil conveyed a conciliatory 
stance towards Argentina while at the same time emphasizing the sovereignty of its international decisions. Finnemore and Sikkink (1998) refer to the significance of belonging to international organizations as a means to confer more legitimacy to a regime. Joining the ATS reflects the Brazilian military regime's need for national and international validation and coincides with the beginning of its liberalization under Geisel's Presidency.

Domestic policy launched the Pro-ethanol Program whereas foreign policy started considering the possible revision of the Treaty in 1991. Although neither Brazil nor the technologically-developed nations had the skills to exploit Antarctic mineral resources, it was essential that the country could take part in this debate. The strategic vision of Geisel and Chancellor Azeredo da Silveira negotiated Brazil's accession into an international regime (May 1975), which until then had only been joined by the NATO and Warsaw Pact member countries. It was the ATS first step in becoming more inclusive in relation to Global South states.

In this first phase, we should note the concentration of power resulting from the delay in achieving consultative status. Of the nine new members admitted to the Treaty, only the oldest, Poland, acquired consultative status after 16 years. In the first 20 years of existence, ATS's decision-making framework remained virtually unchanged, with resolutions in the hands of the original members to the detriment of the others. The ATS demanded "substantial scientific research activity" (Art. IX §2) for the acquisition of consultative status, which contradicted science as a tool of inclusion and allowed for the continuity of post-colonial domination (Elzinga, 2009; Dodds, 2017) ${ }^{7}$. This monopoly of power and resistance to relinquish the status quo could have affected the durability and effectiveness of the regime if it had been maintained in the following phases (Puchala and Hopkins, 1983).

In 1978, the entry into force of the Convention for the Conservation of Antarctic Seals concluded the first phase of the Treaty. That same year, the Iranian fundamentalist revolution disrupted the world oil geopolitics and removed the country from the Western alliance to which it had belonged, contributing to cause a new oil shock.

\section{Who is knocking at the door? The responsive second phase (1979- 91)}

The second phase begins with a new oil shock. The Soviet Union, which had important oil deposits in Siberia, saw an increase in the revenue of its exports. In a political-strategic attempt to position themselves near the Persian Gulf, strengthen the Brezhnev doctrine and achieve greater projection in international politics, the Russians invaded Afghanistan, triggering a resumption of the Cold War. The second phase ends in 1991 with the dissolution of the Warsaw Pact (March) and the break-up of the Soviet Union. That same year, the Madrid Protocol, an environmental document that postponed the prospects of mineral exploration of the continent for 50 years, was signed.

\footnotetext{
${ }^{7}$ According to post-colonial scholars, the lack of indigenous human population and hence of resistance to colonial rule does not exclude Antarctica from being discussed under this novel approach. Post-colonialism in Antarctica reveals itself through other behaviors, like sovereignty claiming, unequal political influence, continuous human presence, among others.
} 
This period witnessed the political strengthening of developing countries claiming for a New International Economic Order at the United Nations forum. According to Puchala and Hopkins (1983), the 1980s was a period of restructuring regimes and the ATS was in line with this process through a revision of the nature and distribution of power. The second phase is known for the increase in new memberships ( 21 countries in 13 years) and for being able to solve unfinished issues.

The wars in the 1980s had repercussions on the international economic and political structure, either by interfering with the supply of oil or through their role in the inflection of the world order. The loss of Iran, Washington's most trusted ally in the Middle East, led the United States to forge new relations with Saudi Arabia, Egypt and Iraq. In 1980, the IranIraq war, brought about by border disputes, was additionally fueled by oil geopolitical interests and ideological antagonisms. The war lasted a decade, ruined both countries and subsequently entailed the annexation of Kuwait by Iraq and the first Gulf War (1990/91). In Afghanistan, Soviets concerned with preserving an enclave aligned with Moscow and faced the resistance of the Mujahideen rebels. The "Soviet Vietnam" eventually triggered the collapse of the great power and paved the way for the so-called clash of civilizations.

Furthermore, the war for the sovereignty of the Falkland/Malvinas Islands exposed the importance of the contiguous region to Antarctica. It rekindled strategic interest in that environment, undermined the Argentine military government and foreshadowed the decline of authoritarian regimes. In the following years, the re-democratization movement encompassed both Latin American and Eastern European countries.

In this second phase, the increasing participation of peripheral countries in the international order affected the ATS structure and promoted a more multipolar balance of power. The ATS went through a "crisis of legitimacy" (Hemmings, 2017, p.3) and became more inclusive and diversified. The binary logic of State accession was overcome, and the membership of Latin American countries and non-aligned powers, like China and India, added to the regime's greater plurality and legitimacy.

China joined the ATS in 1983, as a postponed result of its rapprochement with the West. The first effect of this reconciliation was Resolution 2758, which led to the People's Republic of China accessing the UN instead of Taiwan (October 1971). In 1978, China's severe payment crisis and capital shortages led Deng Xiaoping to review the country's economic policy. Beijing admitted a less ideological development model and adopted a pragmatic foreign policy of greater openness to the world. The "open door" policy encouraged China to join leading international organizations in order to attract foreign investment and became the first step towards its "peaceful rise" (Barnett, 1986).

China's accession into the ATS was rather a political endeavor to enter the international system than a scientific project. Chinese scientists were invited to join the expeditions of the Antarctic programs of Australia, New Zealand and the USA in order to establish cooperation and acquire the necessary skills to undertake their own mission. The first Chinese expedition to Antarctica took place in 1984 and the country achieved consultative status the following year (Brady, 2013). Since then, China has increased its role in Antarctica and invested systematically in the continent.

Two months after China, it was India's turn to join the ATS. The inclusion provoked much controversy because India had previously favored an internationalization of Antarctica and had consistently insisted that this issue should be examined at the United Nations assembly (Villa, 2004). 
Indian foreign policy started getting involved in issues of global concern since the rule of Prime Minister Nehru. The main complaint concerning Antarctica and the ATS were the territorial claims and their Euro-colonial bias. Ironically, Indian attempts to bring the case to the UN (1956 and 1958) were met with the resistance of two former colonies, Argentina and Chile, who mustered forces against what was intended to be an anti-imperialist coalition on the Antarctic issue (Chatuverdi, 2013) ${ }^{8}$.

During the following two decades, domestic problems relegated Antarctica to the sidelines of Indian agenda and it was only under Prime Minister Indira Gandhi that the country dealt with this geopolitical issue by means of an unconventional strategy. In 1982, India sent two scientific expeditions to Antarctica, relying on the principle that the ATS was open to all UN countries and provided the missions were for peaceful purposes (Sharma, 2001). Although the attitude was not unlawful, it was not warranted either, because the Treaty had first to be signed for the mission to be dispatched. The ATS, though, like other international regimes, lacked an enforcement mechanism to control behavioral deviations (Puchala and Hopkins, 1983). On the eve of the twelfth meeting (September 1983), India not only joined the ATS but acquired a consultative status within 24 days, the fastest process in the history of the regime. It was the way the ATS found to control the deviant behavior of that country.

Among the other signatories, India's admission as a consultative member raised the suspicion that it was a strategy to pressure internal divisions and implode the regime. Among the non-aligned countries, the Indian attitude was considered as defection and renunciation of its politically provocative role (Chaturvedi, 2013).

In 1983, another incident agitated the ATS. Because of the apartheid policy, some governments in the Caribbean and Africa, backed by Malaysia, objected to South Africa's membership in the regime. Although the specific target was South Africa, the purpose of the critique was broader and addressed the colonialist nature of Antarctic governance, its lack of transparency and the perpetuation of the privilege of a few countries. The discussion was set against the recent background of the Montego Bay Convention (1982), which allowed conjecturing apropos the internationalization of Antarctica on the basis of the common heritage of mankind. However, the ATS chose not to exclude South Africa, claiming that its domestic policy did not interfere with the Antarctic cooperation regime (Peterson, 1988).

Throughout the 1980s, Malaysia acted as a spokesperson for the non-aligned countries to denounce the ATS. According to the bloc, the illegitimacy of the regime derived from its anachronistic reproduction of colonial political domination assigning the continent and its wealth to the exclusive interest of the consultative parties (Scott, 2011).

At the UN General Assembly (1982/83), Malaysian Prime Minister Mahathir insisted that the organization create a mechanism to supervise the ATS. It was unjustifiable that out of the 157 nations that constituted UN, only 14 should manage a territory amounting to $10 \%$ of the planet's surface without being accountable for it (Krasner, 1985). Despite dismissing the economic exploitation of Antarctica because of its potential environmental impact, Mahathir advocated that the governance of the continent concerned and should benefit all

\footnotetext{
${ }^{8}$ Argentina and Chile feared that, in a forum such as the United Nations, the sovereignty they claimed would be considered illegitimate, and they rushed to overthrow the Indian initiative. It is important to remember that Argentina, in the 1950s, was among the first fifteen economies of the world, making the country a respected player in the territorial cause. It was a Chilean jurist, Julio Escudero Guzman, who suggested the moratorium of territorial claims that supported the Antarctic Treaty.
} 
mankind (Hamzah, 2013). The discourse of the non-aligned countries de-escalated when India, Brazil and China became consultative members of the ATS. However, Malaysian foreign policy persisted on its objections against the ATS until 1998, when an invitation from the New Zealand government to make their Antarctic station available to the scientists from that country moderated the official position.

Denunciations of the ATS by non-aligned countries had the merit of improving the transparency of the meetings, allowing them to be accompanied by non-consultative parties and also by some NGOs. Until 1983, meetings were exclusively attended by consultative members and took place behind closed doors, making the regime look ambiguous and shady. From that point on, and even without the power of decision-making, the other parties were able to play a more active role (Woolcott, 1986).

Although the regime experienced internal contradictions, it was the external pressures, coming from the international power structure, that helped them unfold (Puchala and Hopkins, 1983). According to Keohane (1983), the decision to belong to a regime depends on whether the benefits outweigh the costs. Even if at a disadvantage compared to other members, a participant may choose to join a regime for the assurance it provides (Keohane, 1983). Belonging to the ATS, even as a non-consultative member, was possibly more productive than being left out, especially in the face of uncertainty about the future of Antarctica. The new international balance of forces meant that initial compliance was replaced by greater assertiveness reflecting new national interests. It should be clear, however, that there were no changes in decision-making power, only in the procedures of the meetings. Greater transparency is a change within the regime, but not of regime.

In the second phase, there was an increase in the countries joining the ATS: the inflection point of this internationalization coincides with India's access into the organization (Finnemore and Sikkink, 1998). When India violated the implicit norm and later relinquished its critical stance, a cascade effect led to the international community's legitimizing the ATS. The admission of new players was triggered by the evolving multipolar balance of the international order and hinted at the general assumption regarding a revision of the Treaty in 1991. Participation in a debate that would perhaps allow for the economic exploitation of mineral resources on the continent was an international geopolitical necessity. Faced with the prospect of a change of rules and in order to ensure their presence on the continent, China, India and nineteen other countries hastily joined the ATS and strove to obtain consultative status in time to participate in the decision-making process.

Between 1982 and 1988, the development of a regulatory framework for the exploration of mineral resources in Antarctica (Convention on the Regulation of Antarctic Mineral Resource Activities - CRAMRA) dominated the agenda of the consultative members. The complexity of the issue, the difficulty of accommodating economic needs with the preservation of Antarctica, and the divergence in the interests of each party made it difficult to compose CRAMRA. Three positions had to be conciliated.

Countries with territorial claims (with the exception of France and the United Kingdom) defended their sovereign rights in the exploitation of the claimed territories. The countries with no territorial claims, but developed and with scientific capacity, proposed the unrestricted access to Antarctica with the earnings returning to the investors. Developing countries, lacking technical competence, argued that technology is common to mankind and that there should be an equitable distribution of the benefits of mineral exploitation (Krasner, 1985). 
Discussions around CRAMRA became even more complex when confronted to the theoretical model established by the United Nations Convention on the Law of the Sea (UNCLOS) in 1982. Among the most significant contributions of UNCLOS are the extension of sovereignty for coastal States and the concept of common heritage of mankind for the international seabed. Some countries and consultative members of the ATS felt uneasy about the possibility that this last concept be extended to Antarctica.

The concept of common heritage of mankind originated in 1967 from an evolution of the Latin term res communis omnium and res communis humanitatus (Baslar, 1998) ${ }^{9}$. Despite their similar nature, res communis and common heritage of mankind have different meanings. Both deal with goods and resources that cannot become private property; however, res communis can be the object of access and free exploitation (Mercure apud Montastier, 2009). In the case of common heritage, it is a distribution model in which the benefits of exploitation must be shared by all States and distributed amongst all people regardless of their participation in the extraction (Baslar 1998; Buck 1998). The concept of common heritage of mankind evokes an ethical perspective for a more egalitarian world order, including increased responsibility for the environment.

Amid controversy, the concept of common heritage of mankind established by UNCLOS was discarded from the debates on CRAMRA on account of being regarded as inapplicable to Antarctica. Nonetheless, the UNCLOS provided an argument to claim for an expansion of the territorial demands of the countries on the ATS. The Law of the Sea, upon confirmation of the presence of an underwater platform extending the length of their coastlines, allowed coastal States to claim a continental area beyond the 200 nautical miles limit (article 76). The claim had to be endorsed by scientific data and would then be assessed by a technical committee. The ATS territorial States asserted their claim before the expiration deadline of 10 years established by UNCLOS. However, as Article IV, paragraph 2, of the Treaty prohibited new claims of sovereignty or extension of the existing ones, in order to avoid conflicts, the demands were accompanied by an instruction to postpone analysis sine die (Haward, 2011). The understanding applied to UNCLOS allowed the principles of the ATS to remain intact, so no regime change took place (Krasner 1983; Qasim and Rajan, 1986).

CRAMRA was concluded in Wellington in June 1988 and opened for signature on $25^{\text {th }}$ November of the same year. Regardless of its ability to accommodate conflicting interests and address resources and promote distribution, it was abandoned the following year without being ratified. The rejection began when, in France and Australia, a conjunction of the green and left parties took office. The withdrawal of these two countries disrupted Belgium and Italy and influenced the other signatories (Jacobsson, 2009).

It may seem that CRAMRA's collapse was due to domestic changes in some of the ATS actors, but exogenous international political and environmental factors precipitated this setback. On the one hand, compliance with CRAMRA, despite the care taken in its drafting, could jeopardize rights associated with territorial sovereignty and therefore disturb international balance (Boyd, 2002). On the other hand, the 1980s coincided with the expansion of environmental movements and their growing influence on the international political scenario.

\footnotetext{
${ }^{9}$ In Roman law, the concept of Res Communis omnium refers to those goods that belong to all beings, like the sea, the moving water and the air.
} 
Environmental problems previously circumscribed to scientific discourse gained visibility vis-à-vis public opinion and were incorporated into the political agenda. Incidents of environmental contamination, such as the Union Carbide in Bhopal (1984), the Chernobyl nuclear disaster (1986), the Exxon Valdez Oil spill on the coast of Alaska (1989) and Paradise Harbor in Antarctica (1989), attracted international media attention and revealed, in addition to the lack of transparency, the foolhardiness of companies and governments.

In 1987, the release of "Our Common Future" (Bruntland Report from UN), which proclaimed the so-called sustainable development, asserted that current development should not compromise the wellbeing of future generations. Environmental NGOs denounced the predatory model of development and encouraged green activism. The re-democratization of Latin America and Eastern Europe endorsed the rise of parties along those lines, which eventually led to the United Nations Conference on Environment and Development (UNCED92) in Rio de Janeiro and to the Kyoto Protocol in 1997.

The non-ratification of CRAMRA prompted the drafting of a new protocol to reinforce and not to alter the ATS. The Protocol of Environmental Protection of the Antarctic Treaty (Madrid Protocol) prohibited any activity concerning exploration of Antarctic mineral resources other than for the purpose of scientific research (art. 7). Signed in 1991and ratified in 1998 , it will remain in force until 2048 . Until that date, the protocol is practically invulnerable for it can only be modified with the unanimous consent of the consultative parties and requires the creation of a prior legal regime to define which activities are acceptable and under what conditions. The Madrid Protocol, even without declaring Antarctica a common heritage of mankind, moved toward this notion by recognizing in its preamble that a protection regime of the Antarctic environment "is in the interest of mankind as a whole."

The withdrawing of CRAMRA and the signing of the Madrid Protocol were approved by the Global South states and celebrated by the environmental movement. The rejection of CRAMRA is explained not only by the environmental impact it could cause but also by the political cost of a possible international destabilizing of the region (Boyd, 2002).

Between 1987 and 1991, Greenpeace operated in Antarctica, evidencing the growing influence of transnational non-state actors in the execution of international policy, particularly in the environmental sphere. The NGO set up a station, World Park Base, which monitored the impact that human activities from the scientific bases had on the continent and issued a report describing infractions and negligence in dealing with the environment. If scientists adopted irresponsible practices, such as raw sewage dumped in coastal waters and burning of waste, what was to be expected from the extractive activities? In view of this scenario, Greenpeace began to enjoin the transformation of Antarctica into a natural reserve or world park.

The endorsement of the Madrid Protocol shows growing environmental recognition by the field of international relations and pertains to a new understanding of what constitutes security. In the face of the formal cessation of the Cold War and thus of the risk of a nuclear war, the exclusive military focus shifted to one that comprised environmental risks, such as those arising from climate change, water scarcity and unsustainable exploitation of resources, among others (Serpa, 2013). In 1994, the United Nations Development Program acknowledged the new meaning given to human security by including environmental security as one of its components (Barbosa, 2008).

In this phase, the average time to becoming consultative member in the ATS was reduced to little more than four years. The demand for science production, used as a political 
tool to restrict access to consultative status was alleviated. Even so, the proportion of consultative members hardly changed. In 1991, considering all members (41), the proportion of countries with consultative status (63\%) was the same proportion as at the end of the first phase. The ATS reacted to the criticism regarding its restricted nature by broadening membership and facilitating the transition to consultative status; yet the same percentage of active members remained as in the previous period.

The end of this second phase coincides politically with the fragmentation of the Soviet Union and the dissolution of the Warsaw Pact. In a single movement, the Cold War and the geopolitics of bipolarity - factors that contributed to originating the ATS regime - were discontinued. From the environmental perspective, the Madrid Protocol completed the architecture of the ATS as a system.

Leader Mikhail Gorbachev took office (1985) with the mission of revitalizing the Soviet economy and reversing the stagnation of centralized planning. The restructuring planned by perestroika contrived an introduction of market mechanisms to promote a more efficient economic model followed by a political project of democratic openness and transparency (glasnost). These reforms, however, coincided with a sharp decline in the price of the barrel of oil, jeopardizing revenues from this industry and aggravating the problems of the Soviet economy.

During the last years of the USSR, its monolithic superpower structure was consumed (Hobsbawm, 2000). The political-ideological unity collapsed when Gorbachev refused to apply the Brezhnev doctrine to the Eastern European countries. Within two years (August 1989 to June 1991), the regimes of satellite-states ceased to exist. The Soviet Union itself, once a federation of fifteen republics, split into an equivalent number of independent political and economic entities.

Despite the fact that the ATS was forged by the hegemonic leadership exerted by the USA and the USSR, the decline of the latter did not compromise it. The regime succeeded in overcoming the objections about its colonial character and moved away from its bipolar past, demanding a better alignment to the new world order. Keohane (1983) explains the expansion of regimes based on the increasing returns brought by the entrance of new members. In this case, the rise in membership conferred more legitimacy and recognition to the ATS as an international regime. The endorsement of the Madrid Protocol, because of its detrimental aspect to latent economic interests of the ATS members, gave the impression of credibility and trustworthiness to their purposes.

\section{No more questions for now. The recognised third phase (1992- to date)}

The end of the bipolar system and the rise of new democracies in former Eastern Europe led to territorial fragmentation as well as to new regional integration projects. The Maastricht Treaty (1992) initiated the reunification of Europe and, together with China's turn towards market socialism, was one of the factors that advanced global expansion of economic liberalism. The New World Order increased globalization and the transnationalization of problems related to the environment, drug trafficking and terrorism.

The third phase strengthened the previous restructuring of the ATS, displaying few differences in terms of its composition. In more than two decades, only thirteen countries 
became members of the regime, five of them being veterans that had belonged to the former Soviet Union and Czechoslovakia. Part of this "lack of interest" for joining the ATS may be ascribed to the prohibition of mineral exploitation by the Madrid Protocol and to the global prosperity context that prevailed until 2008.

The most eloquent episode of the new legitimacy attained by the ATS was the access of two countries that had previously disapproved of the regime and championed the internationalization of the continent. Malaysia (2011) and Pakistan (2012) had, for years, opposed what they called the "exclusive, total and arbitrary" nature of the rights granted to the consultative parties (Azraii 1986, 312). With the approval of the Madrid Protocol, the Malaysian campaign against the ATS cooled. In 1998, the New Zealand government made its base in Antarctica available to Malaysian researchers and this bestowal helped subdue the country's foreign policy. Despite the pragmatic need to adjust to the geopolitical and economic challenges of the 21st Century and prioritize its relations with the West, Malaysia, fearing to alienate its allies from the South-South bloc, postponed its accession to the ATS until 2011.

Pakistan's strategy resembled India's, in connection with its reversal of the order of the procedures. Two expeditions were carried out between 1991 and 1993, and a station was erected in Antarctica. Pakistan became a member of the Scientific Committee on Antarctic Research (SCAR) in 1990, but only entered the ATS in 2012.

The legal understanding is that the ATS cannot prohibit non-signatory States from settling on the continent, provided that it is with peaceful intentions and for the purpose of scientific research. On the other hand, the norms of International Law determine that any settlement in Antarctica is under the jurisdiction of the flag it bears, forming a national space within a territory under international administration. As the regime lacks enforcement mechanisms, signatories are compelled to convince other states of the advantages of joining the ATS. In the past, the legal interpretation was more severe. In 1976, for instance, the government of Argentina denied authorization to an Italian expedition leaving from Buenos Aires to Antarctica because the country was not a signatory of ATS (Vicuña, 2000).

In this third phase, the environmental issue became more relevant in the international scenario. The politicization of environmental problems led to the foundation in 1988 of an institution with political and scientific characteristics, the Intergovernmental Panel on Climate Change (IPCC). Furthermore, the UNCED-92 was held in Rio de Janeiro, an event of great media success that mobilized 172 countries and countless heads of state. During the meeting two important agreements were entered: the biodiversity and the climate change conventions. Despite the auspicious beginning, the political and economic demands prompted by the Gulf War and the expansion of globalization hindered the establishment of an international cooperative model in the environmental sphere (Lago, 2006).

The Convention on Biological Diversity (CBD) is a regulatory instrument aimed at ensuring the sustainable use of biodiversity and the protection of the sovereign rights of emerging countries to genetic resources in their territory. The CBD also seeks to reconcile these interests with the compliance to patents and intellectual property norms of the technologically rich countries (Lago, 2006). However, as was the case with CRAMRA and UNCLOS, the legal situation of Antarctica excludes it from the CBD, creating legal uncertainty. Bioprospection executed by private laboratories for commercial purposes in an international environment under territorial claims is a complex and controversial subject that will require legislation compatible with the letter of the ATS (Loose, 2011). 


\section{Conclusion}

The intention of this paper was to avoid a merely descriptive report and to explore, from a systemic perspective, the evolution of the ATS in political, economic and environmental terms. We know that appraisal of the ATS gives rise to many debates and controversies and, in turn, chose to focus instead on how the great structures of the international system served as the theoretical axis of the regime. We identified external drivers, such as the bipolar order, decolonization in the 1970s, and the distension between superpowers, in order to help explain the transformations within the ATS. In the light of changing circumstances, the ATS was compelled to overcome a postcolonial type of rule and admit the active participation of states of the Global South, consider the exploitation of mineral resources and endorse an environmental protocol.

We refrained from drawing too much attention to aspects related to the internal politics of each State, yet some degree of analysis at the unit level was necessary. For their leading role in the evolving of the ATS, the admissions of Brazil, China, India and Malaysia were examined.

Krasner (1985) speculates that if the ATS had been established in the 1970s, it would probably have proclaimed Antarctica as mankind's common heritage, acknowledging the new political balance of forces in the world. The Cold War together with the bipolarity of the turn of the 1950s and a still hesitant decolonization process all contributed to the ATS not being contested to any large degree. It was only when developing nations proceeded to occupy a more outstanding role in international relations that the ATS began favoring a greater number of signatories and improved its legitimacy. The requirements to accede to the status of consultative member lessened and thus the decision-making monopoly was attenuated. The frequency and transparency of the meetings improved and secured a wider debate for consensus-based decision-making. The regime has shown that it has the ability to adapt to changes in the international system, which can explain its durability and robustness.

Despite these advances, the regime is still viewed with reservations by a certain number of scholars. The avowed Eurocentric profile of the ATS reproduces a Westphalian matrix of power akin to post-colonial geography, and a significant part of its scientific output is still being produced by the original members in a unique combination of political and scientific interests. (Walton, 2012; Dodds, 2006; 2010; 2017). Whilst improving in terms of legitimacy and fairness, further research is required in order to evaluate if the ATS is effectively capable of addressing current challenges and global responsibilities.

\section{References}

Azraii Zain. 1986 "The Antarctic Treaty System from the perspective of a state not party to the system". In: Antarctic Treaty System: An assessment. Washington, DC: National Academy Press. pp. 305-313.

Barbosa, Luciana Mendes. 2008. Explorando a Construção de Ameaças: a Securitização das Mudanças Climáticas no Sistema linternacional. Dissertation - PUC/MG Belo Horizonte.. At https:livros01.livrosgratis. com.br/cp091236.pdf [Acessed on 12 December 2018] 
Barnett, A. Doak. 1986 'Ten years after Mao.' Foreign Affairs. June. At https://www.foreignaffairs.com/articles/asia/1986-09-01/ten-years-after-mao [Acessed on 24 November 2018].

Baslar, Kemal. 1998. The Concept of the Common Heritage of Mankind in International Law. Leiden: Martinus Nijhoff Publishers.

Bath, Sergio F. Guarischi. 2000. 'Política Antártica Brasileira'. In: Albuquerque J. A. Guilhon (ed.). Sessenta Anos de Política Externa Brasileira (1930-90): Prioridades, Atores e Política. São Paulo, Annablume, v. 4, pp. 343-353.

Beck, Peter. 2014. The International Politics of Antarctica. New York: Routledge Revivals.

Boyd, Denise. 2002. 'After the protocol: problems and prospects for Antartica.' In: Julia Jabour-Green and Marcus Haward. (eds). The Antarctic: Past, Present and Future. Antarctic CRC Research Report \#28. Hobart. pp.105-111. At http://eprints.utas.edu.au/2661/18/16_Boyd.pdf [Acessed on 15 July 2018]

Brady, Anne Marie (Ed.). 2013. 'China's Antarctic Interests.' In: Anne Marie Brady (ed.) The Emerging Politics of Antarctica. New York: Routledge. pp. 31-48

Carson, Rachel. 1962. Silent Spring. Houghton Mifflin.

Cervo, Amado Luiz; Clodoaldo Bueno. 2012. História da política exterior do Brasil. 4. ed., Brasília: Universidade de Brasília.

Chatuverdi, Sanjay 1986. India and the Antarctic Treaty System: realities and prospects. India Quarterly: a journal of International Affairs, 42 (4): 351-380

2011. Antarctica: 'a Global Knowledge Commons'. Position paper for 6th Open Assembly of the Northern Research Forum, Hveragerdi, Iceland, At https://www.rha.is/static/files/NRF/OpenAssemblies/Hveragerdi2011/position_papers/chaturvedi-antarctica-a_global_knowledge_commonsnrf_2011.pdf [Acessed on 15 May 2018]

2013. 'India and Antarctica: towards post-colonial engagement?' In: Anne Marie BRADY (ed.). The Emerging Politics of Antarctica. New York: Routledge. pp. 5074.

Alan Hemmings, Elizabeth Leane, Daniela Liggett and Juan Francisco Salazar. 2015. 'Nationalism in today's Antarctic'. The yearbook of Polar Law 7: 531-555.

Costa, João Frank. 1961. 'Antártida: o problema político (V)'. Revista Brasileira de Política Internacional, n. 15, setembro. At http://ibri.files.wordpress.com/ 2013/10/rbpi_1961_15.pdf [Acessed on 10 July 2017]

Dodds, Klaus. 2006. 'Post-colonial Antarctica: an emerging engagement'. Polar Record.42 (220). pp. 39-70. doi:10.1017/S0032247405004857

2010. 'Sovereingty watch: claimant states, resources and territory in contemporary Antarctica'. Polar Record 47 (242). pp. 231-243. doi:10.1017/S0032247410000458 and Christy Collis. 2017. 'Post-colonial Antarctica'. In: Dodds, Klaus; Alan D. Hem- 
mings and Peder Roberts (ed). Handbook on the politics of Antarctica. Cheltenham: Edward Elgar Publishing pp.50-68.

Dorst, Jean. 1965. Avant que nature meure. Delachaux et Niestlé.

Elzinga, Aant. 2009. 'Origins and limitations of the Antarctic treaty'. In: Berkman, Paul Arthur; Michael A. Lang; David Walton and Oran Young. (ed). Science diplomacy: Antartica, Science and the governance of international spaces. Washington: Smithsonian Institution, pp 59-67. At: http://www.atsummit50.org/ media/book-10.pdf. [Acessed on 11 June 2017].

Ferreira, Felipe Rodrigues Gomes. 2009. O Sistema do Tratado da Antártica: Evolução do Regime e seu Impacto na Política Externa Brasileira. Brasília: Fundação Alexandre Gusmão. At http:www.funag.gov.br/biblioteca/dmdocuments/Tratado da_antartica.pdf

Finnemore, Martha and Kathryn Sikkink. 1998. 'International norm dynamics and political change.' International Organization, 52 (4): 887-917 At http://www. jstor.org/stable/2601361 [Acessed on 07 Februray 2018].

Hamzah, B.A. 2013. 'The Malaysian journey to the Antarctic: a glimpse at public policy dynamics'. In Anne Marie BRADY (ed.). The Emerging Politics of Antarctica. New York: Routledge. pp. 96-108

Haward, Marcus. 2011. 'Introduction: the Antarctic Treaty 1961-2011'. The Polar Journal, 1 (1): 1-4, June At http://www.tandfonline.com/doi/pdf/ 10.1080/2154896X.2011.586555 [Acessed on 26 August 2017]

Hemmings, Alan and Klaus Dodds. 2009. Frontier vigilantism? Australia and contemporary representation of Australian Antarctic Territory. Australian Journal of Politics and History, 55 (4):513-529

2011 Why did we get an International Space Station before an International Antarctic Station?. The Polar Journal, 1 (1): 5-16 DOI: 10.1080/2154896X.2011.569377

------. 2012. Considerable values in Antarctica. The Polar Journal. 2 (1): 139-156 DOI: 10.1080/2154896X.2012.679565

2013. Utopian framings of the polar regions.The Polar Journal. 3 (2): 273-276. DOI: $10.1080 / 2154896 \times .2013 .868088$

2017. Antartic Politics in a transforming Global Geopolitics. In: Klaus Dodds, Alan Hemmings and Peder Roberts (eds). Handbook on the Politics of Antarctica. Edward Elgar Publishing. pp. 507-522.

-------, Klaus Dodds and Peder Roberts. 2017. Introduction. In: Klaus Dodds, Alan Hemmings and Peder Roberts (eds). Handbook on the Politics of Antarctica. Edward Elgar Publishing. pp. 1-15

Hobsbawn, Eric. 2000. Age of Extremes: the Short Twentieth Century (1914-1991). London: Abacus.

Jacobsson, Marie. 2009. 'Building the international legal framework for Antartica'. In: Paul Arthur Berkman, Michael LANG, David Walton and Oran Young (eds) Science Diplomacy: Antartica, Science and the Governance of International Spaces. 
Washington, DC: Smithsonian Institution. pp. 1-15. At http://www.atsummit50.org/media/book-10.pdf [Acessed on 11 March 2017]

Keohane, Robert. 1983. 'The demand for international regimes' In Stephen Krasner (ed.). International Regimes: Ithaca and London: Cornell University Press. pp141- 171

Krasner, Stephen. 1983. 'Structural causes and regime consequences: regimes as intervening variables.' In: Stephen Krasner (ed.). International regimes. Ithaca and London: Cornell University Press. pp 1-21.

1985. Structural Conflict: the Third World against Global Liberalism. London: University of California Press.

Lago, Andre Correa. 2006. Estocolmo, Rio e Joanesburgo: o Brasil e as Três Conferências Ambientais das Nações Unidas. Brasília: FUNAG At http://livros01.livrosgratis.com.br/al000189.pdf.

Loose, Fabrício Ferreira. 2011. Bioprospecção na Antártida. Dissertation - UFRS At http://www.lume.ufrgs.br/ bitstream/handle/10183/31731/000782535.pdf?...1

Mattos, Leonardo Faria de. 2015. O Brasil e a adesão ao Tratado da Antártica: uma análise de política externa no governo Geisel. Dissertation - UFF at http://www.ppgest.uff.br/images/

Montastier, Alice. 2009. Principe de Souverainté et Risques Environmentaux. Dissertation Université de Grenoble, 2009. At http://sfr-europe-international.upmf-grenoble.fr/servlet/com.univ.collaboratif.utils. LectureFichiergw?ID_FICHIER=1343379275460[Acessed on 21 May 2018]

Orrego-Vicuña, Francisco. 2000. 'Port state jurisdiction in Antarctica: a new approach to inspection, control and enforcement.' In: Davor VIDAS (ed.). Implementing the Environmental Protection Regime in Antarctica. Dordrecht: Springer Science + Business Media. pp. 45-70.

Peterson, M. J. 1988. Managing the Frozen South: the Creation and Evolution of the Antarctic Treaty System. Berkeley: University of California Press.

Puchala, Donald and Raymond Hopkins. 1983. 'International regimes: lessons from inductive analysis.' In: Stephen KRASNER (ed.). International Regimes. Ithaca and London: Cornell University Press. pp 61-91.

Qasim S. Z.and H.P. Rajan. 1986. 'The Antarctic Treaty System from the perspective of a new member.' In: Antarctic Treaty System. An assessment. Washington, DC: National Academy Press. pp. 345- 374.

Scott, Shirley. 2011. 'Ingenious and innocuous? Article IV of the Antarctic Treaty as imperialism.' The Polar Journal, 1 (1): 51-62 At http://www.tandfonline.com/doi/abs/10.1080/2154896X.2011.568787 [Acessed on 26 September 2017]

Serpa, Antonio. 2013. 'Introdução: segurança internacional e mudanças climáticas ontem e hoje'. In: Clovis Brigagão, Maira Segura and Rafael Seabra (eds.). Mudanças Climáticas e Segurança Internacional: Desafios à Prevenção de Conflitos. Rio 
de Janeiro: Educam. pp. 88-92.

Sharma, Satya. 2001. Breaking the Ice in Antarctica: the First Indian Wintering in Antarctica. New Delhi: New Age International Publishers.

Viana, Suhayla Mohamed Khalil. Política externa independente: fundamentos e reflexos nas relações internacionais do Brasil (1961-1964). 2009. In: Annals ANPUH - XXV Simpósio de História, Fortaleza. At http://anpuh.org/anais/wp-content/uploads/mp/pdf/ANPUH.S25.1327.pdf [Acessed on 16 June 2017].

Villa, Rafael Antonio Duarte. 2004. A Antártida no Sistema Internacional: Análise das Relações entre Atores Estatais e Não Estatais com Base na Perspectiva da Questão Ambiental. São Paulo: Hucitec.

Woolcott, Richard A. 1986. 'The interaction between the Antarctic Treaty System and the United Nations System'. In: Antarctic Treaty System. An assessment. Washington, DC: National academy Press. pp. 375-390.

Young, Oran. 2011.'Effectiveness of international environmental regimes: existing knowledge, cutting edge themes, and research strategies.' In: PNAS, 108 (50): 1985319860. At https: www.pnas.org/cgi/doi/10.1073/pnas.1111690108 [Acessed on 02 June 2017] 